\title{
Determination of heavy metal pollution index of ground water of village Wallipur in Ludhiana district
}

\author{
Singla Chetan ${ }^{1 *}$ Sanjay T. Satpute $^{2}$ and Garg Sunil ${ }^{2}$ \\ ${ }^{1}$ Director Farms, Punjab Agricultural University, Ludhiana-141 004 (Punjab), INDIA \\ ${ }^{2}$ Department of Soil and Water Engineering, Punjab Agricultural University, Ludhiana-141 004 (Punjab), INDIA \\ *Corresponding author. E-mail: chetan_singla@pau.edu
}

Received: July 20, 2016; Revised received: February 8, 2017; Accepted: May 17, 2017

\begin{abstract}
The objective of the study was to reveal the seasonal variations in the groundwater quality with respect to heavy metals contamination near Buddha Nullah in Ludhiana district. To get the extent of trace metals contamination, groundwater samples from tube wells were randomly collected from 16 different points on both sides along the course of Buddha Nullah from areas of Bhamian Kalan, Khasi Kalan and Wallipur Kalan villages of Ludhiana district during first fortnight of June (Pre-monsoon), first fortnight of November (Post-monsoon) and first fortnight of January (Winter season) during the year 2013-14. The concentrations of toxic and heavy metals such as metalloids B, As, $\mathrm{Pb}$; alkaline earth metals $\mathrm{Mg}, \mathrm{Ca}$; alkali metals $\mathrm{Na}, \mathrm{K}$; transition metals $\mathrm{Cr}, \mathrm{Mn}, \mathrm{Fe}, \mathrm{Cu}, \mathrm{Zn}, \mathrm{Cd}$ and non metal S were determined. The heavy metal pollution index (HPI) was calculated. Most of the parameters were found within permissible limit of BIS, 2004. The average values of concentration of $\mathrm{Ca}, \mathrm{Cr}, \mathrm{Mn}$, As and $\mathrm{Pb}$ for pre-monsoon season was higher than average concentration of post-monsoon and winter season. Overall HPI calculated based on the mean concentration of the heavy metals was found to be $18.11,15.32$ and 16.10 for pre-monsoon, post-monsoon and winter season, respectively, which was below the critical pollution index value of 100 . The study recommended proper treatment to the sewage water which is being discharged into the Buddha Nullah.
\end{abstract}

Keywords: Buddha Nullah, Groundwater pollution, Heavy metal pollution index, Ludhiana

\section{INTRODUCTION}

The water unsafe for human consumption and/or hygienic purposes represents a significant health risk for the exposed population. Those at the greatest risk of waterborne disease are infants and young children, the elderly and the people living under unsanitary conditions (WHO Std. 2006). Globally, nearly a billion people still lack access to improved sources of drinking water, and about 2.5 billion lack improved sanitation and an estimated 2,000 children under the age of five die every day from diarrhoeal diseases and of these some 1,800 deaths are linked to water, sanitation and hygiene (UNICEF, 2013). The deterioration of groundwater quality could be attributed to the anthropogenic as well as natural causes. Urban and industrial sectors not only utilize the available water but also discharge a considerable amount of wastewater. In Punjab and the rest of India, the most important anthropogenic factor responsible for groundwater pollution is urban and industrial wastewater which carries the trace elements like arsenic (As), chemicals like cyanide and harmful pesticides. This wastewater is often not treated before its release into sewerage drains. The most common disposal of wastewater is its use as crop irrigation. Direct release of untreated effluents to land and water bodies can potentially contaminate air, surface, groundwater as well as soils, and eventually the crops. Present discharge of sewage in Ludhiana is 636 million litre per day (MLD) whereas sewage treatment plants (STPs) of capacity 466 MLD are in operation (PPCB proceedings, 2016). Trace metal contaminations are important due to their potential toxicity for the environment and human beings (Gueu et al., 2007; Lee et al., 2007; Adams et al., 2008; Vinodhini and Narayanan, 2008). Monitoring and assessment of the water pollution has become a very critical area of study because of direct implications of water pollution on the aquatic life and the human beings. Large industries include those in the production of gold, aluminium, fertilizer, pulp and paper, textiles and chlor-alkali, as well as automotive engineering industries and electroplating units, which are a major hazardous waste source, are included with the large/medium industries for assessment. Among small-scale industries, chemicals, textiles, dyes/ pigments, pesticides and leather tannings are selected as potential hazardous wastes (Misra and Pandey, 2005). A recent study (Dheri et al., 2007) showed that the concentration of lead $(\mathrm{Pb})$, chromium $(\mathrm{Cr})$, cadmium $(\mathrm{Cd})$ and nickel $(\mathrm{Ni})$ were not only significantly higher in water samples of Buddha Nullah drain but also in those collected from shallow hand-pumps located within its vicinity of $200 \mathrm{~m}$ as compared to 
deep tubewell water. The contamination of groundwater by heavy metals is a serious ecological problem as some of them like As $(0.05 \mathrm{mg} / \mathrm{l}$ maximum permissible limit) and $\mathrm{Pb}(0.05 \mathrm{mg} / \mathrm{l}$ maximum permissible limit $)$ are toxic even at low concentrations and are nondegradable and can be bio-accumulated through food chain (Kar et al., 2008). The spatial study of heavy metals by using heavy metal pollution index would be helpful in identifying and quantifying trends in water quality (Prasad and Kumari, 2008; Reza and Singh, 2010) and can provide the accumulated information and assessments in a form that resource management and regulatory agencies can use to evaluate alternatives and make necessary decisions. In view of rationale presented, the study was planned to assess the groundwater pollution near the Buddha Nullah.

\section{MATERIALS AND METHODS}

Location: The study area Wallipur village is located in Ludhiana district of Punjab State. It lies approximately between $30^{\circ} 51^{\prime} 10^{\prime \prime}$ to $30^{\circ} 57^{\prime} 20^{\prime \prime} \mathrm{N}$ latitude and $75^{\circ} 46^{\prime}$ $00^{\prime \prime}$ to $75^{\circ} 56^{\prime} 20^{\prime \prime} \mathrm{E}$ longitude. The average height above mean sea level is $247 \mathrm{~m}$. Ludhiana district has a population of more than 3.4 million (Census of India, 2011). Ludhiana city was founded on a ridge of Buddha Nullah a tributary of river Sutlej and approximately 170 MLD untreated sewage of the city is discharged into Buddha Nullah (PPCB proceedings, 2016). In addition, to the city sewage, the Nullah receives the treated, partially treated and untreated toxic effluents from a multitude industries located in Ludhiana city. As a result of perennial flow of sewage in Buddha Nullah, it has become an open sewer. The Buddha Nullah confluence into river Sutlej near village Wallipur after travelling about $55 \mathrm{~km}$ from its originating point at Machhiwara (Jindal and Sharma, 2011).

Collection of samples: Sixteen groundwater samples from different tubewells were collected from village Wallipur of Ludhiana district along both sides of Buddha Nullah (Fig. 1). The groundwater samples were collected during first fortnight of June (Pre-monsoon), first fortnight of November (Post-monsoon) and first fortnight of January (Winter season) during the year

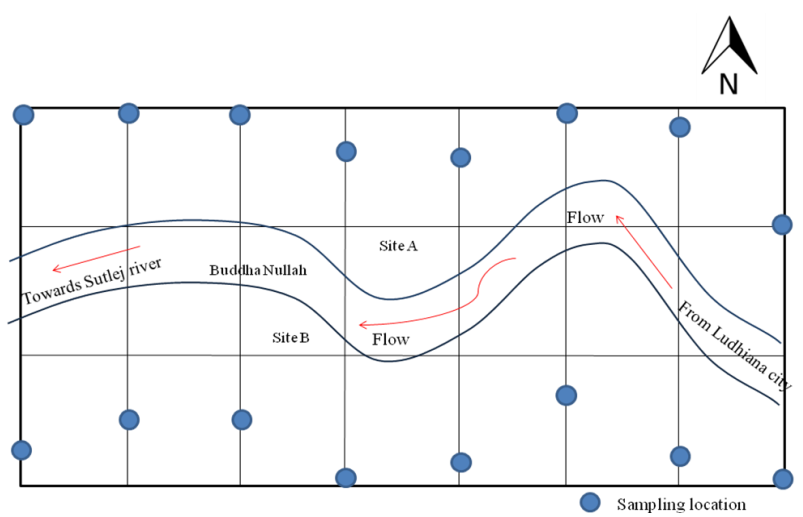

Fig. 1. Sampling location of the study area.

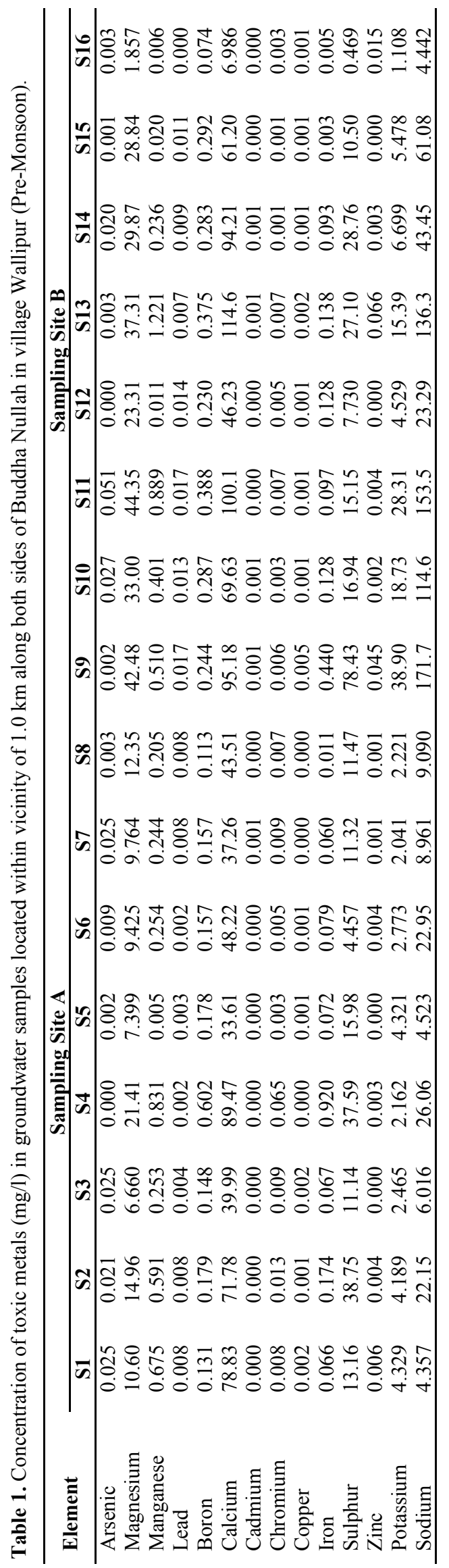


Singla Chetan et al. / J. Appl. \& Nat. Sci. 9 (2): 1139 - 1145 (2017)
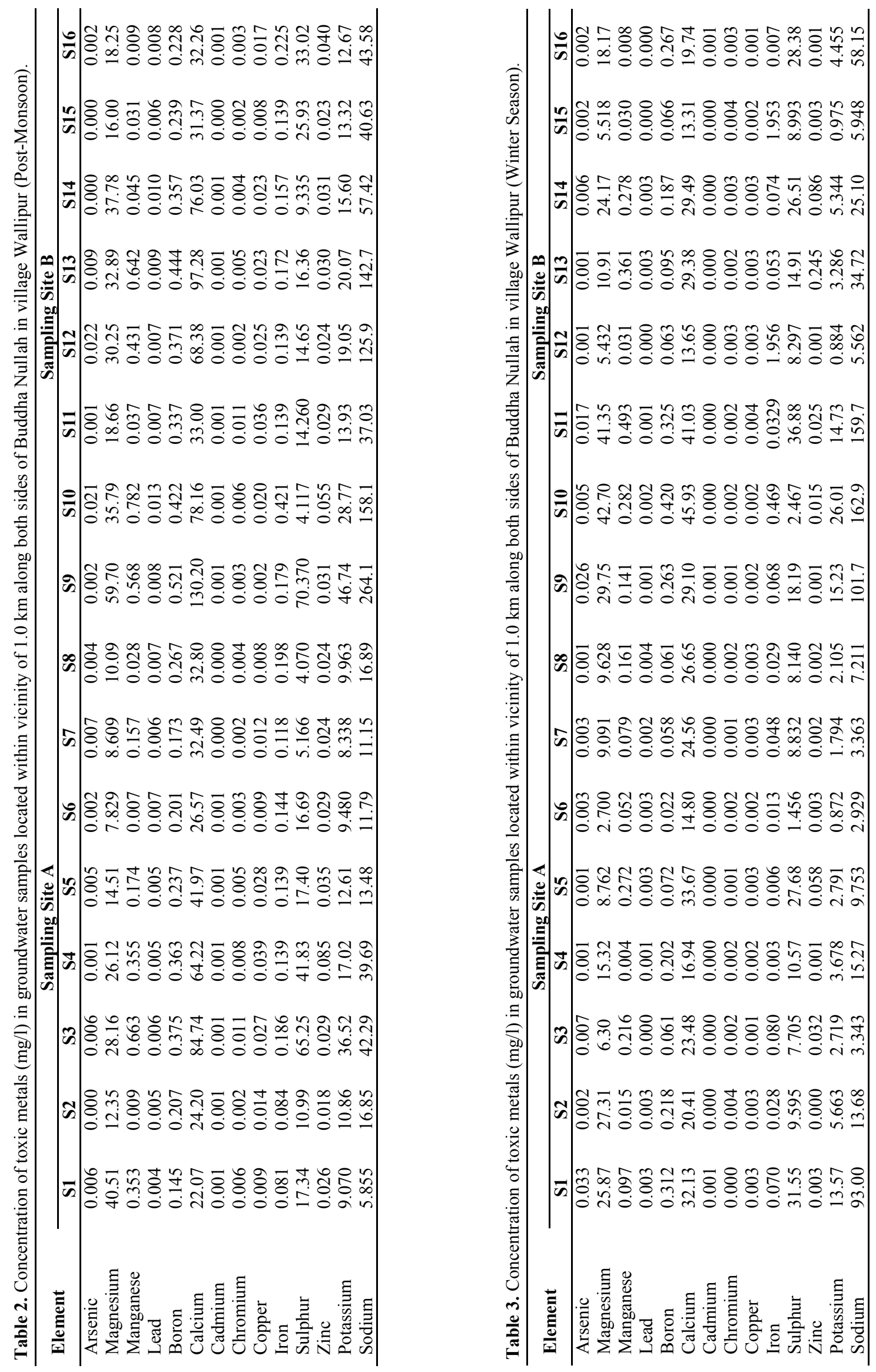
Table 4. Descriptive statistics of heavy metals in groundwater, BIS standard limits.

\begin{tabular}{lcccc}
\hline Parameter (mg/l) & Mean, $\mathbf{~ g / l}$ & Std. Dev & Coefficient of variation (\%) & BIS Std: 2004 (IS: 10500) \\
\hline Pre-monsoon & & & & 0.01 \\
\hline Arsenic & 0.0136 & 0.014 & 104.6 & 0.1 \\
Manganese & 0.3970 & 0.350 & 88.2 & 0.01 \\
Lead & 0.0082 & 0.005 & 61.9 & 0.5 \\
Boron & 0.2399 & 0.128 & 53.5 & 0.05 \\
Copper & 0.0013 & 0.001 & 91.7 & 0.01 \\
\hline Post-monsoon & & & & 0.1 \\
\hline Arsenic & 0.0055 & 0.007 & 120.1 & 0.01 \\
Manganese & 0.2682 & 0.266 & 99.2 & 0.5 \\
Lead & 0.0071 & 0.002 & 30.6 & 0.05 \\
Boron & 0.3054 & 0.105 & 34.3 & 0.01 \\
Copper & 0.0188 & 0.010 & 55.1 & 0.1 \\
Winter season & & & & 0.01 \\
\hline Arsenic & 0.0069 & 0.010 & 136.2 & 0.5 \\
Manganese & 0.1575 & 0.142 & 89.8 & 0.05 \\
Lead & 0.0018 & 0.001 & 73.6 & 70.3 \\
Boron & 0.1683 & 0.118 & 31.6 & \\
Copper & 0.0025 & 0.001 & & \\
\hline
\end{tabular}

2013-14. The spacing between each sampling site was approximately $1.0 \mathrm{~km}$ from each other. Before collection of water sample, each tube well was run for about 10 to 15 minutes to ensure the removal of stored water in the pump assembly and suction pipe. Water sample was then collected in a 1.0 litre plastic bottle after rinsing it with the running water. These bottles were then stored in an icebox and transported to the laboratory for analysis where these were kept in a deep freezer. The samples were then analyzed for toxic and heavy metals viz. boron (B), sodium $(\mathrm{Na})$, magnesium $(\mathrm{Mg})$, sulphur $(\mathrm{S})$, potassium $(\mathrm{K})$, calcium $(\mathrm{Ca})$, chromium $(\mathrm{Cr})$, manganese $(\mathrm{Mn})$, iron $(\mathrm{Fe})$, copper $(\mathrm{Cu})$, zinc $(\mathrm{Zn})$, arsenic $(\mathrm{As})$, cadmium $(\mathrm{Cd})$, lead $(\mathrm{Pb})$ using inductively coupled argon plasma atomic emission spectroscopy (ICAP-AES).

Calculations: The quality of groundwater was assessed by using heavy metal pollution index. Heavy metal pollution index (HPI) is a method of rating which shows the composite influence of individual heavy metal on the overall quality of water and it is an effective tool to characterize the ground water pollution as it combines several parameters to arrive at a particular value which can be compared with the critical value to assess the level of pollution load. In Table 5 the methodology of HPI calculation has been presented in detail. Mean concentrations of the five heavy metals were used for the HPI determination. The rating is a value between 0 and 1 and it is an arbitrary value between 0 and 1 and its selection depends upon the importance of individual quality concentrations in a comparative way or it can be assessed by making values inversely proportional to the recommended standard $\left(\mathrm{S}_{\mathrm{i}}\right)$ for the corresponding parameter (Horton 1965; Mohan et al.1996). Water quality and its suitability for drinking purpose can be examined by determining its quality index (Mohan et al., 1996; Prasad and Kumari, 2008; Prasad and Mondal, 2008).

$$
\mathrm{HPI}=\frac{\sum_{\mathrm{n}=1}^{\mathrm{n}} \mathrm{w}_{\mathrm{i}} \mathrm{X} \mathrm{Q}_{\mathrm{i}}}{\sum_{\mathrm{m}=1}^{\mathrm{n}} \mathrm{W}_{\mathrm{i}}}
$$

Where $W_{i}=$ Unit Weightage of $i^{\text {th }}$ parameters, $Q_{i}=$ sub index of the $i^{\text {th }}$ parameter, $n=$ is the number of parameters considered. Weighted arithmetic index method was used for calculation of HPI. The weightage (Wi) was taken as the inverse of standard permissible value $(\mathrm{Si})$. The sub-index of (Qi) of the parameter was calculated by

$\mathrm{Q}_{\mathrm{i}}=\sum_{\mathrm{i}=1}^{\mathrm{n}} \frac{\mid \mathrm{M}_{\mathrm{i}}-\mathrm{I}_{\mathrm{i}}}{\left(\mathrm{S}_{\mathrm{i}}-\mathrm{I}_{\mathrm{i}}\right)}$

Where,

$\mathrm{M}_{\mathrm{i}}=$ is the monitored value of heavy metal of $\mathrm{i}^{\text {th }}$ parameter

$\mathrm{I}_{\mathrm{i}}=$ Ideal value of the $\mathrm{i}^{\text {th }}$ parameter

$\mathrm{S}_{\mathrm{i}}=$ Standard permissible value of $\mathrm{i}^{\text {th }}$ parameter

The quantity (Mi -Ii) indicates numerical difference of the two values, ignoring the algebraic sign; that is the absolute value. Generally, the critical heavy metal pollution index value is 100 (Prasad and Bose, 2001).

\section{RESULTS AND DISCUSSION}

Chemical analysis of groundwater samples in village Wallipur (Pre-Monsoon): The groundwater samples were analyzed for toxic and heavy metals. The mean and maximum value of concentration of As in groundwater was found out to be $0.0136 \mathrm{mg} / \mathrm{l}$ and $0.051 \mathrm{mg} / \mathrm{l}$, respectively, with a standard deviation of 0.014. Of the total samples, its concentration in $37.5 \%$ samples was found to be more than the maximum permissible limit of $0.01 \mathrm{mg} / \mathrm{l}$. Similar results were also reported by Hundal et al., 2009. The mean and maximum value of concentration of $\mathrm{Ca}$ was found to be $64.42 \mathrm{mg} / \mathrm{l}$ and $114.6 \mathrm{mg} / \mathrm{l}$, respectively and in $37.5 \%$ samples, concentration of $\mathrm{Ca}$ was more than the maximum permissible limit of $75 \mathrm{mg} / \mathrm{l}$ whereas the mean and maximum value of concentration of Mn was 0.397 $\mathrm{mg} / \mathrm{l}$ and $1.221 \mathrm{mg} / \mathrm{l}$, respectively which was more 
Table 5. Mean HPI of the groundwater samples for pre-monsoon, post-monsoon and winter season.

\begin{tabular}{|c|c|c|c|c|c|c|c|}
\hline Parameter & $\begin{array}{l}\text { Mean Value } \\
\text { (Mi) (mg/l) }\end{array}$ & $\begin{array}{l}\text { Standard per- } \\
\text { missible value } \\
(\mathrm{Si})(\mathrm{mg} / \mathrm{l}) \\
\end{array}$ & $\begin{array}{l}\text { Highest de- } \\
\text { sirable value } \\
\text { (Ii) }(\mathrm{mg} / \mathrm{l}) \\
\end{array}$ & $\begin{array}{l}\text { Unit weight } \\
\text { age (Wi) }\end{array}$ & $\begin{array}{l}\text { Sub Index } \\
\text { (Qi) }\end{array}$ & Wi X Qi & HPI \\
\hline \multicolumn{8}{|c|}{ Pre-monsoon season } \\
\hline Arsenic & 0.0136 & 0.05 & 0.01 & 20.00 & 8.91 & 178.13 & \multirow{6}{*}{18.1} \\
\hline Manganese & 0.3970 & 0.3 & 0.1 & 3.33 & 148.5 & 495. & \\
\hline Lead & 0.0082 & 0.05 & 0.01 & 20.00 & 4.53 & 90.62 & \\
\hline Boron & 0.2399 & 1 & 0.5 & 1.00 & 52.03 & 52.03 & \\
\hline \multirow{2}{*}{ Copper } & 0.0013 & 1 & 0.05 & 1.00 & 5.13 & 5.132 & \\
\hline & & & & \multicolumn{2}{|l|}{$\Sigma \mathrm{Wi}=45.33$} & $\Sigma W i x Q i=820.90$ & \\
\hline \multicolumn{8}{|c|}{ Post-monsoon season } \\
\hline Arsenic & 0.0055 & 0.05 & 0.01 & 20.00 & 11.25 & 225 & \multirow{6}{*}{15.32} \\
\hline Manganese & 0.2682 & 0.3 & 0.1 & 3.33 & 84.09 & 280.31 & \\
\hline Lead & 0.0071 & 0.05 & 0.01 & 20.00 & 7.344 & 146.88 & \\
\hline Boron & 0.3054 & 1 & 0.5 & 1.00 & 38.91 & 38.91 & \\
\hline \multirow[t]{2}{*}{ Copper } & 0.0188 & 1 & 0.05 & 1.00 & 3.289 & 3.29 & \\
\hline & & & & \multicolumn{2}{|l|}{$\Sigma \mathrm{Wi}=45.33$} & $\Sigma$ WixQi=694.39 & \\
\hline \multicolumn{8}{|c|}{ Winter season } \\
\hline Arsenic & 0.0069 & 0.05 & 0.01 & 20.00 & 7.66 & 153.2 & \multirow{6}{*}{16.10} \\
\hline Manganese & 0.1575 & 0.3 & 0.1 & 3.33 & 28.75 & 95.83 & \\
\hline Lead & 0.0018 & 0.05 & 0.01 & 20.00 & 20.47 & 409.4 & \\
\hline Boron & 0.1683 & 1 & 0.5 & 1.00 & 66.35 & 66.35 & \\
\hline \multirow[t]{2}{*}{ Copper } & 0.0025 & 1 & 0.05 & 1.00 & 5 & 5 & \\
\hline & & & & $\Sigma \mathrm{Wi}=45.33$ & & $\Sigma$ WixQi $=729.78$ & \\
\hline
\end{tabular}

than the maximum permissible limit of $0.1 \mathrm{mg} / \mathrm{l}$ and similar trend was observed in $\mathrm{Pb}$. The concentration of $\mathrm{Mn}$ and $\mathrm{Pb}$ was more than maximum permissible limit in $75 \%$ and $31.2 \%$ samples. The standard deviation was 0.350 and 0.005 for $\mathrm{Mn}$ and $\mathrm{Pb}$, respectively. The mean and maximum value of $B$ was found out to be $0.239 \mathrm{mg} / 1$ and $0.608 \mathrm{mg} / \mathrm{l}$ which was higher than the maximum permissible limit of $0.5 \mathrm{mg} / \mathrm{l}$. Toxic metals like $\mathrm{S}, \mathrm{Zn}, \mathrm{Cd}$ was found to be below maximum permissible limits in all the samples whereas Fe was found to be more than maximum permissible limit of $0.3 \mathrm{mg} / 1$ in one sample and $\mathrm{Mg}$ was found to be more than permissible limit $(30 \mathrm{mg} / \mathrm{l})$ in $25 \%$ samples (Table 1). These results are supported by many other studies who found high level of heavy and toxic metal concentrations (Kalicharan 2007; Kaur et al., 2014; Garg et al., 2015).

Chemical analysis of groundwater samples in village Wallipur (Post-Monsoon): During post monsoon season, the mean and maximum value of concentration of As in groundwater was found out to be $0.0055 \mathrm{mg} / \mathrm{l}$ and $0.022 \mathrm{mg} / \mathrm{l}$, respectively, with a standard deviation of 0.007 . In $12.5 \%$ samples, concentration of As was more than permissible limit whereas the mean and maximum concentration of $\mathrm{Mn}$ was found to be 0.27 $\mathrm{mg} / \mathrm{l}$ and $0.78 \mathrm{mg} / \mathrm{l}$, respectively and in $56.25 \%$ samples, its concentration was more than the maximum permissible limit of $0.1 \mathrm{mg} / \mathrm{l}$. The standard deviation for $\mathrm{Mn}$ was found to be 0.266 . The mean and maximum value of concentration of Ca was $54.73 \mathrm{mg} / \mathrm{l}$ and $130.2 \mathrm{mg} / \mathrm{l}$, respectively and in $25 \%$ samples, concentration of $\mathrm{Ca}$ was found to be more than maximum permissible limit. Similarly, the mean and maximum value of concentration of $\mathrm{Pb}$ was $0.007 \mathrm{mg} / \mathrm{l}$ and 0.013 $\mathrm{mg} / \mathrm{l}$, respectively, with a standard deviation of 0.002 . The maximum value was higher than the maximum permissible limit of $0.01 \mathrm{mg} / \mathrm{l}$. The maximum value of $\mathrm{B}$ was found out to be $0.521 \mathrm{mg} / \mathrm{l}$ which was higher than the maximum permissible limit of $0.50 \mathrm{mg} / \mathrm{l}$. Toxic metals like $\mathrm{S}, \mathrm{Zn}, \mathrm{Cd}$ was found to be below maximum permissible limits in all the samples whereas $\mathrm{Fe}$ was found to be more than maximum permissible limit of $0.3 \mathrm{mg} / \mathrm{l}$ in one sample and $\mathrm{Mg}$ was found to be more than permissible limit $(30 \mathrm{mg} / \mathrm{l})$ in $31 \%$ of total samples (Table 2). The mean concentration of As, $\mathrm{Mn}, \mathrm{Pb}, \mathrm{S}, \mathrm{Zn}$ and $\mathrm{Ca}$ were less than the concentration during pre-monsoon season which may be due to dilution from recharge contribution from diluted Nullah water.

Chemical analysis of groundwater samples in village Wallipur (Winter Season): During winter season, the mean and maximum value of concentration of As in groundwater was found out to be $0.0069 \mathrm{mg} / \mathrm{l}$ and $0.033 \mathrm{mg} / \mathrm{l}$, respectively, with a standard deviation of 0.01 . In $19 \%$ samples, concentration of As was more than permissible limit whereas the mean and maximum concentration of $\mathrm{Mn}$ was found to be 0.16 $\mathrm{mg} / \mathrm{l}$ and $0.49 \mathrm{mg} / \mathrm{l}$, respectively and in $50 \%$ samples, its concentration was more than the maximum permissible limit of $0.1 \mathrm{mg} / \mathrm{l}$. The standard deviation for $\mathrm{Mn}$ was found to be 0.142 . The mean and maximum value of concentration of Ca was $25.90 \mathrm{mg} / 1$ and $45.93 \mathrm{mg} / \mathrm{l}$, respectively but in none of the samples it was found to be above maximum permissible limit. Similarly, the mean and maximum value of concentration of $\mathrm{Pb}$ was $0.0018 \mathrm{mg} / \mathrm{l}$ and $0.004 \mathrm{mg} / \mathrm{l}$, respectively, with a standard deviation of 0.001 . In all samples, it was below maximum permissible limit of $0.01 \mathrm{mg} / \mathrm{l}$. The 


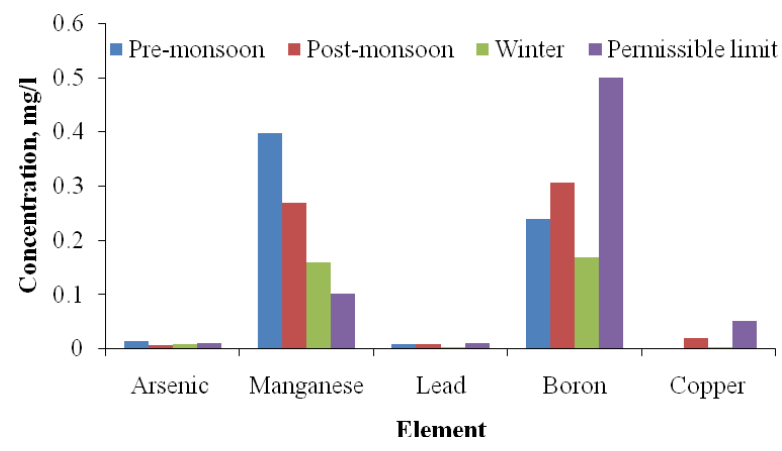

Fig. 2. Average concentration of heavy metals ( $A s, M n, P b, B$ and $\mathrm{Cu}$ in Pre-monsoon, Post-monsoon and winter season.

mean and maximum value of $\mathrm{B}$ was found out to be 0.016 and $0.42 \mathrm{mg} / \mathrm{l}$ which was less than the maximum permissible limit of $0.50 \mathrm{mg} / \mathrm{l}$. Toxic metals like $\mathrm{S}, \mathrm{Zn}$, $\mathrm{Cd}$ was found to be below maximum permissible limits in all the samples whereas $\mathrm{Fe}$ was found to be more than maximum permissible limit of $0.3 \mathrm{mg} / \mathrm{l}$ in two samples and $\mathrm{Mg}$ was found to be more than permissible limit (30 mg/l) in one sample (Table 3 ).

Comparison between chemical analysis of pre-monsoon, post-monsoon and winter season groundwater samples in village Wallipur: The premonsoon, post-monsoon and winter season ground water samples were analyzed for toxic and heavy metals concentration as shown in Tables 1, 2 and 3 . The results of average concentration of heavy metals (mg/l) for pre-monsoon, post-monsoon and winter season are presented in Fig. 2. Perusal of the Fig. 2 revealed that the average values of concentration of $\mathrm{B}$ and $\mathrm{Fe}$ for post-monsoon season was higher than the pre-monsoon and winter seasons but the average concentration of $\mathrm{As}, \mathrm{Zn}, \mathrm{Cd}, \mathrm{Pb}$ and $\mathrm{Mn}$ for pre-monsoon season was higher than average concentration of post-monsoon and winter season. This may be due to the fact that during post monsoon season, diluted water due to runoff from Buddha Nullah has entered in to ground as recharge component.

Quite higher concentration of heavy and toxic metals were measured in the groundwater, which may be attributed to the discharge of industrial effluents from dyeing, electroplating, woolen industries, domestic and agricultural waste and other anthropogenic activities around the Buddha Nullah which leads to groundwater pollution in adjoining areas.

Statistics of heavy metals in groundwater: The descriptive statistics of heavy metals in groundwater for pre-monsoon, post-monsoon, winter season and Bureau of Indian Standards (BIS, 2004) limits are presented in Table 4. For pre-monsoon season, among the examined variables, $\mathrm{Mn}, \mathrm{Ca}$ has the highest mean $(0.397 \mathrm{mg} / \mathrm{l})$ followed by B $(0.239 \mathrm{mg} / \mathrm{l})$, As $(0.013$ $\mathrm{mg} / \mathrm{l}), \mathrm{Pb}(0.008 \mathrm{mg} / \mathrm{l})$ and $\mathrm{Cu}(0.001 \mathrm{mg} / \mathrm{l})$. Also, $\mathrm{Mn}$ recorded the highest standard deviation of $0.350 \mathrm{mg} / \mathrm{l}$, this is followed by $\mathrm{B}, \mathrm{As}, \mathrm{Pb}$ and $\mathrm{Cu}$. For post-

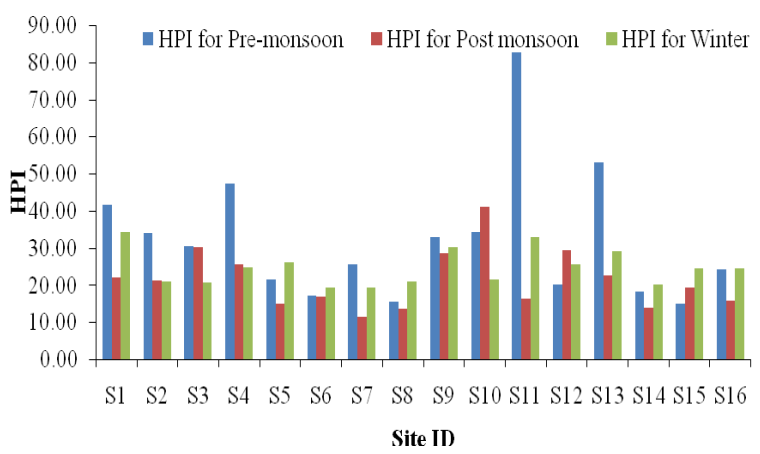

Fig. 3. HPI for pre-monsoon, post-monsoon and winter season at different groundwater sampling sites.

monsoon and winter season, B recorded the highest mean and $\mathrm{Mn}$ recorded highest standard deviation. The standard deviation shows that the pollution degree in this area was uniform. On the pattern of the relative variation, the result of the coefficient of variation (C.V.) showed that all the examined variables are heterogeneous. Arsenic for example tops the list with a value of $104.6 \%$ for pre-monsoon, $120.1 \%$ for postmonsoon and $136.2 \%$ for winter season, respectively. The mean values of $\mathrm{As}$ and $\mathrm{Pb}$ for pre-monsoon and post-monsoon season were at par with the maximum permissible limit of BIS (2004). Similarly, the mean value of Mn was higher than the maximum permissible limit of BIS (2004), for pre-monsoon, post-monsoon and winter season as shown in Table 4. The mean value of $\mathrm{B}$ and $\mathrm{Cu}$ was less than the maximum permissible limit.

In order to calculate the HPI of the water, the mean concentration values of the selected metal ( $\mathrm{As}, \mathrm{Mn}, \mathrm{Pb}$, $\mathrm{B}$ and $\mathrm{Cu}$ ) have been taken into account (Prasad and Mondal, 2008). HPI was also calculated separately for each sampling location to compare the pollution load and assess the groundwater quality of the selected sites (Fig. 3). The critical pollution index value, above which the overall pollution level should be considered unacceptable, is 100 (Prasad and Kumari, 2008; Prasad and Mondal, 2008). Overall HPI for the groundwater samples was found to be $18.11,15.32$ and 16.10 for pre-monsoon, post-monsoon and winter season, respectively (Table 5). The highest HPI was 82.56 at site $\mathrm{S} 11,40.93$ at site $\mathrm{S} 10$ and 34.14 at site 1 for premonsoon, post-monsoon and winter season, respectively. Results revealed that the HPI for post-monsoon and winter season was less than pre-monsoon which may be due to rainfall contribution to Nullah water which contributes to groundwater. The similar results were also reported by Nazari and Sobhanardakani (2015); Nasrabadi (2015) ; Sobhanardakani (2016). Overall HPI value indicated that the groundwater quality in village Wallipur on both sides of Buddha Nullah is not critically polluted with respect to these heavy metals during pre-monsoon, post-monsoon and winter season. 


\section{Conclusion}

The present study revealed the maximum values of concentration of $\mathrm{Ca}, \mathrm{Cr}, \mathrm{Mn}, \mathrm{As}$ and $\mathrm{Pb}$ in groundwater sample during the pre-monsoon and post-monsoon to be higher than the maximum permissible limit. Though the water was not found to be critically polluted with respect to heavy metals, the situation is still a matter of concern as concentrations of most of the metals were found to be above the desirable maximum value prescribed for the water by BIS (2004). Overall Heavy Metal Pollution index (HPI) calculated based on the mean concentration of the heavy metals for premonsoon, post-monsoon and winter season was below the critical pollution index value of 100 for groundwater near Buddha Nullah.

\section{ACKNOWLEDGEMENTS}

The Indian Council of Agricultural Research, New Delhi, India is acknowledged for providing the financial support for AICRP-IWM through Indian Institute of Water Management, Bhubaneswar

\section{REFERENCES}

Adams, R. H., Guzmán Osorio, F. J. and Zavala Cruz, J. (2008). Water repellency in oil contaminated sandy and clayey soils. Int. J. Environ. Sci. Tech., 5 (4): 445-454

Bureau of Indian Standards (2004). Specification for drinking water-Indian Standard (IS: 10500), New Delhi.

Census of India, (2011). District Census Handbook Ludhiana Village and Town wise Primary Census Abstract (PCA) Retrieved on February 07, 2017 from

http://www.censusindia.gov.in/2011 census/dchb/0307_ PART_B_DCHB\%20_LUDHIANA.pdf

Dheri, G. S., Brar, M. S. and Malhi, S. S. (2007). Heavy metal concentration of sewage contaminated water and its impact on underground water, soil and crop plants in alluvial soils of north western India. Commun. in Soil Sci. Plant Anal., 38: 1353-1370

Garg S., Singla, C. and Aggarwal, R. (2015). Evaluation of groundwater quality using contamination index in Ludhiana, Punjab (India). J. Industrial Pollution Control, 31(1): 33-39

Gueu, S., Yao, B., Adouby, K. and Ado, G. (2007). Kinetics and thermodynamics study of lead adsorption on to activated carbons from coconut and seed hull of the palm tree. Int. J. Environ. Sci. Tech., 4 (1): 11-17

Horton, R. K. (1965). An index number system for rating water quality. Journal of Water Pollution Control Federation, 37: 300-305

Hundal, H. S., Singh, K. and Singh, D. (2009). Arsenic content in ground and canal waters of Punjab, North-West India. Environ Moni. Assess., 154(1-4): 393-400

Jindal, R. and Sharma, C. (2011). Studies on water quality of Sutlej river around Ludhiana with reference to physicochemical parameters. Environ. Moni. Assess., 174:417425

Kalicharan (2007). Occurrence and Distribution of Iron in Groundwater in Some parts of Uttar Pradesh', Proceed- ings of National Seminar on Agriculture Development and Rural Drinking Water held at Bhopal: 355-367

Kar, D., Sur, P., Mandal, S. K., Saha, T. and Kole, R. K. (2008). Assessment of heavy metal pollution in surface water. Int. J. Environ. Sci. Tech., 5(1):119-124

Kaur, T., Sharma, K. and Sinha A. K. (2014). Extent of heavy/trace metals/elements contamination of groundwater resources in Ludhiana and Patiala, Punjab. Man in India, 94(4): 585-596

Lee, C. L., Li, X. D., Zhang, G., Li, J., Ding, A. J. and Wang, T. (2007). Heavy metals and $\mathrm{Pb}$ isotopic composition of aerosols in urban and suburban areas of Hong Kong and Guangzhou, South China Evidence of the long-range transport of air contaminants. Environ. Pollut., 41(2): $432-447$

Misra, V. and Pandey, S. D. (2005). Hazardous waste, impact on health and environment for development of better waste management strategies in future in India. Environment International, 31(3): 417-431

Mohan, S. V., Nithila, P. and Reddy, S. J. (1996). Estimation of heavy metal in drinking water and development of heavy metal pollution index. J. Environ. Sci. Health A., 31(2): 283-289

Nasrabadi, T. (2015). An index approach to metallic pollution in river waters. Int. J. Environ. Res., 9(1): 385-394.

Nazari A. and Sobhanardakani S. (2015). Assessment of pollution index of heavy metals in groundwater resources of Qaleh Shahin plain (2013-2014). J Kermanshah Univ Med Sci., 19(2):102-108

PPCB proceedings. (2016). Implementation of Action Plan for abatement of pollution in critically polluted area of Ludhiana and Mandi Gobindgarh: 1-50

Prasad, B. and Bose, J. M. (2001). Evaluation of heavy metal pollution index for surface and spring water near a limestone mining area of the lower Himalayas. Environmental Geology, 41: 183-188

Prasad, B. and Kumari, S. (2008). Heavy metal pollution index of ground water of an abandoned open cast mine filled with fly ash: A case study. Mine Water Environ., 27(4): 265-267

Prasad, B. and Mondal, K. K. (2008). The impact of filling an abandoned opencast mine with fly ash on ground water quality: A case study. Mine Water Environ., 27 (1): 40-45

Reza, R. and Singh, G. (2010). Heavy metal contamination and its indexing approach for river water. Int. J. Environ. Sci. Tech., 7(4): 785-792

Sobhanardakani, S. (2016). Evaluation of the water quality pollution indices for groundwater resources of Ghahavand plain, Hamadan Province, Western Iran. Iranian J. Toxicology, 10(3): 35-40

UNICEF (2013). Report of the Joint Monitoring Programme: Progress on Sanitation and Drinking-Water. UNICEF/ WHO; New York, NY, USA.

Vinodhini, R. and Narayanan, M. (2008). Bioaccumulation of heavy metals in organs of fresh water fish Cyprinus carpio (Common carp). Int. J. Environ. Sci. Tech., 5(2): 179-182

World Health Organization. (2006). Guidelines for Drinking Water Quality; Incorporating First Addendum, 3rd ed., Recommendation, vol. 1.WHO, Geneva, 1-668. 